\title{
Characterization of Guazuma ulmifolia Lam. seed gum and its effect on the activity of Metarhizium anisopliae (Metschn.) Sorokin on Bemisia tabaci Genn
}

\section{Caracterización de la goma de semillas de Guazuma ulmifolia lam. y su efecto sobre la actividad de Metarhizium anisopliae (Metschn.) Sorokin en Bemisia tabaci Genn}

Jesse A. Pacheco-Aguirre ${ }^{1}$, Esaú Ruiz-Sánchez ${ }^{1}$, Luis Chel-Guerrero. ${ }^{2}$, Luis Jorge Corzo-Ríos $^{3}$, Alfonzo Pérez-Gutiérrez ${ }^{1}$, Arturo Reyes-Ramírez ${ }^{1}$, Horacio S. BallinaGómez ${ }^{1 *}$

1División de Estudios de Posgrado e Investigación, Tecnológico Nacional de México, Campus Conkal. Avenida Tecnológico s/n, Conkal, Yucatán, C.P. 97345, Mexico.

${ }^{2}$ Facultad de Ingeniería Química, Universidad Autónoma de Yucatán, Campus de Ciencias Exactas e Ingenierías, Periférico Norte km. 33.5, Col. Chuburná de Hidalgo Inn, Mérida, Yucatán, C.P. 97203, Mexico.

${ }^{3}$ Unidad Profesional Interdisciplinaria de Biotecnología, Instituto Politécnico Nacional, Av. Acueducto s/n, Barrio La Laguna, Col. Ticomán, D.F., C.P. 07340, Mexico.

${ }^{*}$ Corresponding author

E-mail address: horacio.ballina@itconkal.edu.mx (H. S. Ballina-Gómez)

Article history:

Received: 24 April 2020 / Received in revised form: 31 July 2020 / Accepted: / 14 August 2020 / Published online: 1 October 2020.

https://doi.org/10.29267/mxib.2020.5.4.34

\begin{abstract}
The present study was conducted to evaluate the functional properties of seed gum of Guazuma ulmifolia (GG) and its effects on the entomotoxic activity of the fungus Metarhizium anisopliae (MET) on whitefly nymphs (Bemisia tabaci). The GG was extracted from mature fruit seeds in distilled water at $60^{\circ} \mathrm{C}$ and precipitated in ethanol. The quantity of gum extracted from the seed of G. ulmifolia was $67.1 \mathrm{~g} / \mathrm{kg}$. This gum showed a dispersion in water of $79.6 \%$ and thermal stability. The rheological studies indicated that GG had a non-Newtonian behavior and high viscosity at low concentrations. The swelling index (SI) and water dispersion (WDIS) of GG were
\end{abstract}


determined at different temperatures. The apparent viscosity $(\mu)$ of GG was measured using an AR-2000 rheometer. An entomotoxic bioassay was carried out under greenhouse conditions using MET $\left(1 \times 10^{8}\right.$ conidia $\left.\mathrm{mL}\right)$ suspended in aqueous solutions of $G G$ at 0.2 and $0.5 \%$. These solutions were sprayed on eggplant leaves infested with $B$. tabaci to evaluate their entomopathogenic effect. The use of GG improved the lethal effect of MET on $B$. tabaci nymphs by $44.4 \%$. This increase in nymphal mortality caused by MET when combined with GG, suggest that GG could be a good alternative as a carrier and protective agent for entomopathogenic fungi used in pest control.

Keywords: fungi activity, nymph mortality, seed protection, tree species, viscosity.

\section{RESUMEN}

El presente estudio se realizó para evaluar las propiedades funcionales de la goma de Guazuma ulmifolia (GG) y su efecto en la actividad entomotóxica del hongo Metarhizium anisopliae (MET) sobre ninfas de mosca blanca (Bemisia tabaci). La GG se extrajo de semillas de frutos maduros en agua destilada a $60^{\circ} \mathrm{C}$ y se precipitó en etanol. La cantidad de goma extraída de la semilla de G. ulmifolia fue de $67.1 \mathrm{~g} / \mathrm{kg}$, dicha goma mostró una dispersión en agua de $79.6 \%$ y estabilidad térmica. Los estudios reológicos indicaron que la GG tuvo un comportamiento no-Newtoniano y alta viscosidad a bajas concentraciones. El índice de hinchamiento (SI) y dispersión de agua (WDIS) de la GG se determinó a diferentes temperaturas. La viscosidad aparente $(\mu)$ de la GG se obtuvo empleando un reómetro AR-2000. Se realizó un bioensayo entomotóxico usando MET ( $1 \times 10^{8}$ conidios $\mathrm{mL}$ ) suspendido en diferentes soluciones de $\mathrm{GG}(0.2-0.5 \%)$ en agua. Dichas soluciones se rociaron sobre hojas de berenjena infestadas con $B$. tabaci para evaluar su efecto entomopatogénico. El uso de la GG mejoró el efecto letal de MET sobre ninfas de $B$. tabaci en un $44.4 \%$. Este incremento en la mortalidad de ninfas por efecto de MET en combinación con GG, sugiere que GG podría ser una buena alternativa como agente portador y protector de hongos entomopatógenos usados en control de plagas.

Palabras clave: especie arbórea, hongo entomopatógeno, mortalidad de ninfas, protección de semillas, viscosidad.

\section{INTRODUCTION}

Gums or hydrocolloids are long chain polysaccharides, characterized by their property of forming viscous dispersions or gels in water. Natural gums can be found in gummy slimes from fermentation processes, seaweeds, plant exudates, plant extracts and seed flours (Pacheco-Aguirre et al., 2010). Gums has been used in industrial products as thickeners, stabilizers, emulsifiers, coatings, encapsulants and carriers. All these functional properties depend on their mechanical (texture) and flow (viscosity) properties (Milani \& Maleki, 2012). Currently, research on non-conventional gums has opened new avenues on novel uses of these products and have replaced the use of synthetic gums (El Kader et al., 2008). Several studies has found promising results with gums from seeds of the Fabaceae Leucaena leucocephala, Delonix regia, Adenanthera pavonina, Caesalpinia pulcherrima, Gleditsia triacanthos and Sophora japonica (El Kader et al., 
2008; Pacheco-Aguirre et al., 2010; Cerqueira et al., 2009), the Malvaceae Durio zibethinus and Guazuma ulmifolia (Mirhosseini \& Amid, 2012; Carrascosa \& Lorenzo, 2013), the Brassicaceae Lepidium perfoliatum and Alyssum homolocarpum (Koocheki et al., 2009; Koocheki et al., 2010), and the Lamiaceae Ocimum basilicum (Hosseini et al., 2010). G. ulmifolia is a tree that grows in tropical zones of Mexico, South America and in the Caribbean. This tree is considered a multipurpose tree which is used as ground cover and forage source in cattle production (Villa et al., 2009; Manríquez et al., 2011), as well as cosmetics and medicament (Berenguer et al., 2007; Lopes et al., 2009; Alonso \& Salazar, 2008; Patel et al., 2012). Gum obtained from bark and leaves of G. ulmifolia has been use as strengthener and fixer of color in archaeological paintings (Ruiz, 2009; Carrascosa \& Lorenzo, 2013). Moreover, the gum of G. ulmifolia seed has effects on the control of mosquito larvae through its attraction and retention (Gallardo, 1993), however the physicochemical characteristics such as viscosity, water dispersion, swelling index among others, of gum of G. ulmifolia have not been studied, which allows to be used more widely in control of infestation in horticultural crops.

Metarhizium anisopliae (MET) is an entomopathogenic fungus that has been widely used as a biological control agent. Several works have reported that MET is an excellent control agent against whitefly (Bemisia tabaci) infestation in horticultural crops. Faria \& Wraight (2001) have reported that isolates of MET are highly virulent at nymphs of $B$. tabaci. Flores et al., (2012) indicated that MET is effective against the eggs, first, second and third instar nymphs, and pupae of B. tabaci. Norhelina et al., (2013) evaluated five MET strains against $B$. tabaci nymphs finding that strain GJ4 was highly infective to nymphs. A well know constraint in the use of biological control fungi is the effect of environmental factors such as solar ultraviolet radiation (UV-A and UV-B) and high temperatures (Rangel et al., 2004). These factors affect the conidia viability, which results in inactivation and germination inhibition (Ojeda et al., 2011; Herlinda et al., 2018). To counteract these effects, the use of natural gums may be feasible as carrier and protective agent for microorganisms, which could be due to water blinding capacity and reflected in the viscosity and swelling index, among other physicochemical parameters, protecting them from extreme weather conditions, such as high temperature and UV radiation (Yin et al., 2019; Pacheco-Aguirre et al., 2016). The present work was carried out to evaluate the functional properties of seed gum from Guazuma ulmifolia and its application as carrier to enhance MET activity on the whitefly (B. tabaci) nymphs.

\section{MATERIALS AND METHODS}

\subsection{Plant material}

Guazuma ulmifolia fruits (Fig. 1) were collected in the municipalities of Merida and Conkal, Yucatan, Mexico. Dried ripe fruits were collected directly from the field, selecting healthy fallen fruits from six trees. The fruits were processed in the laboratory of Microbiology at the Tecnologico Nacional de México, Campus Conkal, Yucatan. These fruits were passed through a fodder crusher (TRF 300G TRAPP, Jaraguá do Sul/SC, Brasil) to break the husk and release the seeds. The seeds were cleaned sequentially through a $4(4.76 \mathrm{~mm}), 8(2.38 \mathrm{~mm})$ and $16(1.19 \mathrm{~mm})$ mesh to remove all husk residues. The husk residues below the size of the seeds were removed by fluidized bed. Clean seeds were stored in polyethylene bags at $4{ }^{\circ} \mathrm{C}$ until use. 


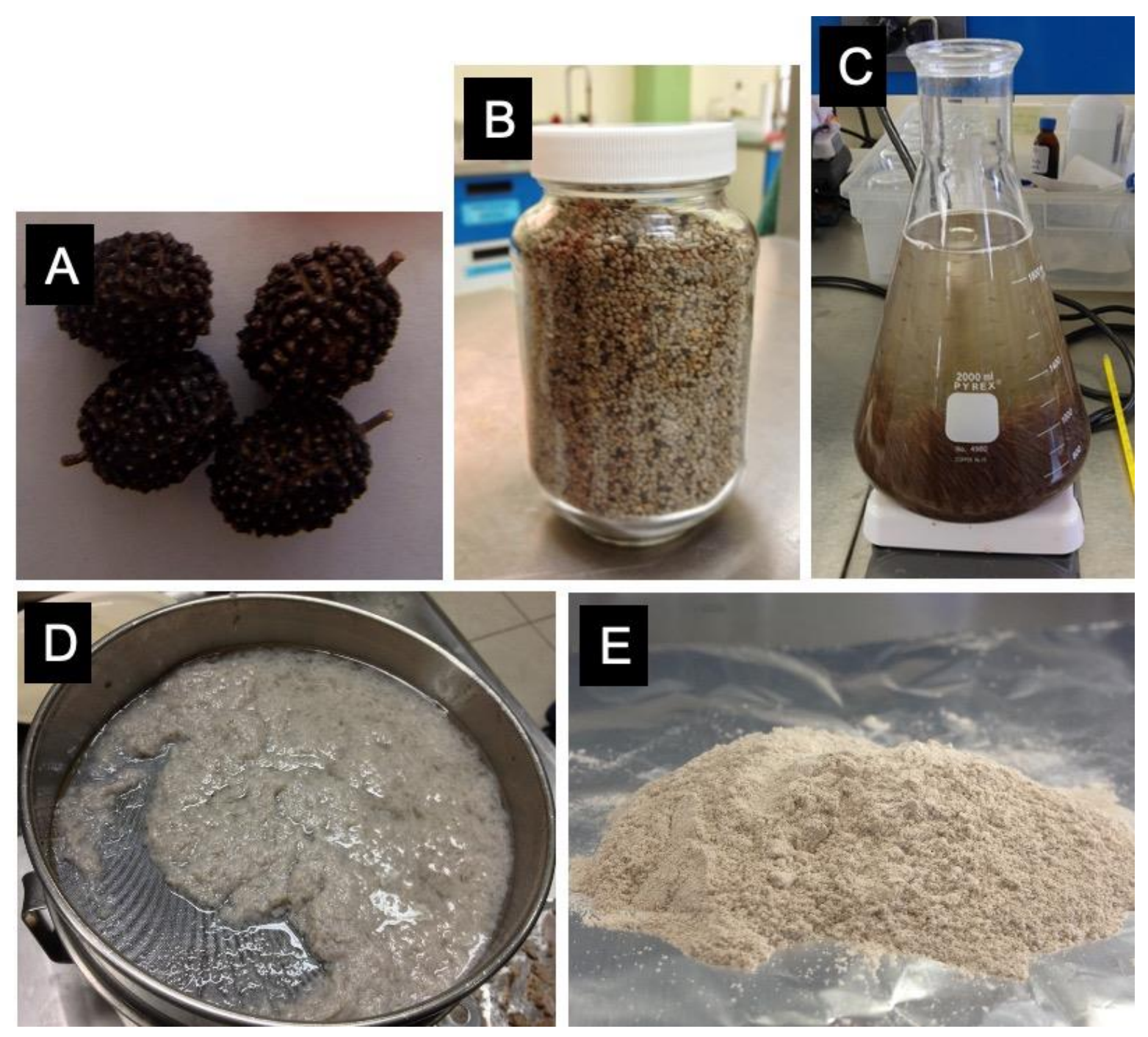

Fig. 1. Extraction process of Guazuma ulmifolia seed gum. A) Fruits, B) Seeds, C) Seed shaking, E) Gum precipitated with alcohol, F) Gum flour.

\subsection{Gum extraction}

The seed gum (GG) extraction was carried out as documented by Capitani et al. (2015), with some modifications. Briefly, seeds were suspended in water $(1: 15 \mathrm{w} / \mathrm{v}, \mathrm{pH} 7)$ and heated to $60{ }^{\circ} \mathrm{C}$ under constant agitation for $1 \mathrm{~h}$. The suspension was then filtered sequentially through a 42 and 100 mesh ( 351 and $147 \mathrm{~mm}$, respectively) to separate gum from seeds. This operation was repeated modifying relation seeds:water (1:5 p/v) and the gum collected in the filtrates were mixed and precipitated in pure ethanol (1:2, filtrate/ethanol), dried at $60{ }^{\circ} \mathrm{C}$ for $12 \mathrm{~h}$ in a circulating air oven (Imperial V Lab-Line Model $3476 \mathrm{M}$, Boston, MA), and milled (Thomas-Wiley Laboratory Mill Model 4, Swedesboro, NJ) to an 80 mesh $(173 \mathrm{~mm})$ size with a proximate composition of $0.89 \%$ protein, $10.47 \%$ ash, $7.10 \%$ fat, $2.93 \%$ crude fiber, and $78.6 \%$ total carbohydrates, determined according to AOAC International (1997). 


\subsubsection{Swelling index and water dispersion}

Swelling index $(\mathrm{SI})$ and water dispersion (WDIS) were determined by using the method reported by Pacheco-Aguirre et al., (2010), taking $40 \mathrm{ml}$ of a $1 \%(\mathrm{w} / \mathrm{v})$ dilution of GG extract in distilled water in four $50 \mathrm{ml}$ centrifuge tubes. The tubes were heated separately in a water bath to 4 different temperatures $\left(30,50,70\right.$ and $\left.90^{\circ} \mathrm{C}\right)$ for 30 minutes. To prevent the gum swell sedimentation during heating, the tubes were constantly stirred and covered with plastic film to avoid water loss. After heating, the tubes were centrifuged $(2,120 \mathrm{~g}, 15 \mathrm{~min}$ ) in an ultracentrifuge (Z-300K Hermle, Wehingen, Germany) and the pellet was recovered and weighed $\left(W_{p}\right)$. Both the precipitated and the supernatant were dried at $105^{\circ} \mathrm{C}$ for $4 \mathrm{~h}$ and dry solids were calculated for the precipitated $\left(\mathrm{W}_{\mathrm{ps}}\right)$ and supernatant $\left(\mathrm{W}_{\mathrm{s}}\right)$. SI was calculated (Equation (1)) as the ratio of the weight of the hydrated gum after centrifugation (g) to its dry mass (g).

$$
\mathrm{SI}=\frac{\mathrm{Wp}}{\mathrm{Wps}} \quad \begin{aligned}
& \text { (hydrated gum }(\mathrm{g})) \\
& (\text { dry gum in precipitate paste }(\mathrm{g}))
\end{aligned}
$$

The $W_{D I S}$ is the percentage of dry mass in supernatant to the dry mass of whole gum sample $\left(\mathrm{W}_{0}\right)$ :

$$
\mathrm{W}_{\mathrm{DIS}}=\frac{\mathrm{Ws}}{\mathrm{Wo}_{\mathrm{o}}} \times 100 \quad \begin{aligned}
& (\text { soluble solids }(\mathrm{g})) \\
& (\text { dry mass of whole gum sample }(\mathrm{g}))
\end{aligned}
$$

\subsubsection{Viscosity assay}

Viscosity $(\mu)$ of seed gum was determined by using the method reported by PachecoAguirre et al., (2010). This was carried out using an AR-2000 rheometer (TA Instrument) with a cone and plate geometry (20 mm diameter and $4^{\circ}$ angle) and a shear rate range from 1 to $500 \mathrm{~s}^{-1}$. To evaluate the viscosity of the GG, three temperature ramps $(15,25$ and $45^{\circ} \mathrm{C}$ ) were used. Each analysis was done in triplicate.

\subsection{Whitefly colony and bioassay}

Adult whiteflies (B. tabaci) were originally collected from field-established habanero pepper (Capsicum chinense Jacq.) in Conkal, Yucatan, Mexico. The colony that has been maintained for three years was kept in entomological cages made of anti-aphid mesh with aluminum frame, in a greenhouse at $28 \pm 6{ }^{\circ} \mathrm{C}$ with a natural photoperiod $(\mathrm{L}: \mathrm{D})$ of approximately $12: 12 \mathrm{~h}$. Insects in the cages were fed on 40 to 70 day-old $C$. chinense. These plants were grown in $2 \mathrm{~L}$ plastic pots containing peat moss (Cosmopeat ${ }^{\circledR}$ ) and fertilized daily with triple 19 (NPK 19-19-19), $1 \mathrm{~g} / \mathrm{L}$ (Chan et al., 2013). 
Eggplant seedlings were planted in $2 \mathrm{~L}$ pots, filled with $0.4 \mathrm{~kg}$ of autoclaved soil mixture ( $\% \mathrm{v} / \mathrm{v}): 70 \%$ soils (the soil had medium-textured, with $0.93 \% \mathrm{~N}$, and the total contents of $\mathrm{P}, \mathrm{K}, \mathrm{Ca}$ and $\mathrm{Mg}$ of $2.45,3.5,49.38$ and $2.63 \mathrm{~g} \mathrm{~kg}-1$, respectively), $10 \%$ commercial substrate (Cosmopeat ${ }^{\circledR}$ ) and $20 \%$ fine grave. Plants (30 cm height) were exposed to $B$. tabaci for 15 days at $28 \pm 6{ }^{\circ} \mathrm{C}$, as described by Chan et al., (2013). When eggs and nymphs were observed in the eggplant leaves, the biological activity of MET was evaluated as follows. Spores of MET were obtained from the Laboratory of Plant Health Services from Yucatan, Mexico. This MET strain has been used for microbial management of Schistocerca piceifrons piceifrons Walker (1870) and has also been lately used for $B$. tabaci. Conidia were harvested from 15-day fungal colonies grown in sabouraud dextrose agar (SDA) medium, suspended in sterile distilled water $(0.05 \%$ Tween 80) and filtered through five layers cheesecloth to remove mycelia mats and fragments of SDA (Chan et al., 2013). Concentrations of conidial suspensions were adjusted to $1 \times 10^{8}$ conidia $\mathrm{mL}$ with the use of a standard Neubauer chamber. Conidial suspensions ( $5 \mathrm{~L}$ suspension) were sprayed until running with a manual sprayer (Table 1 ) to the abaxial surface of $B$. tabaci-infested leaves. Seven days after MET was sprayed, leaves were excised and observed in a stereoscopic microscope (Leica EZ4) to evaluate nymphal mortality. Observation of nymphal mortality was carried out in sections of $8.58 \mathrm{~cm}^{2}$ per leaf (Ruiz-Sánchez et al., 2011). The experiment was arranged in a completely randomized design using four replicates for each treatment (Table 1).

Table 1. Spore suspensions sprayed to Bemisia tabaci nymphs.

\begin{tabular}{ll}
\hline Treatment & Description \\
\hline Control & Water (no fungal spore). \\
MET & $\begin{array}{l}\text { Metarhizium anisopliae }\left(1 \times 10^{8} \text { conidia } \mathrm{mL}\right) \text { in distilled water. } \\
\text { MET-GG 0.2\% }\end{array}$ \\
$\begin{array}{l}\text { M. anisopliae }\left(1 \times 10^{8} \text { conidia } \mathrm{mL}\right)+\text { seed gum of } \text { G. ulmifolia }(0.2 \% \\
\text { w/v) in distilled water. }\end{array}$ \\
MET-GG 0.5\% & $\begin{array}{l}\text { M. anisopliae }\left(1 \times 10^{8} \text { conidia } \mathrm{mL}\right)+\text { seed gum of } \text { G. ulmifolia }(0.5 \% \\
\text { w/v) in distilled water. }\end{array}$ \\
\hline
\end{tabular}

\subsubsection{Data analysis}

Analysis of variance and means comparison test (Tukey, $p<0.05$ ) were performed by Statgraphics Centurion software (15.2.06 version). Prior to run, data of percent mortality were transformed to $\arcsin [y=\arcsin (\operatorname{sqrt} y / 100)])$ to fit normality of data..

\section{RESULTS}

\subsection{Yield of seed and seed gum from G. ulmifolia}

The yield of seeds was $148.5 \mathrm{~g}$ per kg of fruits. Gum extraction yielded $67.1 \mathrm{~g}$ per $\mathrm{kg}$ of seeds, with approximate contents of $0.89 \%$ protein, $10.47 \%$ ash, $7.10 \%$ fat, $2.93 \%$ crude fiber, and $87.19 \%$ total carbohydrates. The seed gum of G. ulmifolia (GG) 
showed an increase in conductivity from 23 to $451 \mu \mathrm{S} / \mathrm{cm}$ when concentration increased from 0.5 to $1.0 \% \mathrm{GG}$ in water, respectively. The $\mathrm{pH}$ remains constant $(\mathrm{pH} 5.7)$ despite the increase in the concentration of GG.

\subsubsection{Swelling index and water dispersion}

The GG showed $79.6 \pm 2.4 \%$ of water dispersion (WDIS) and $12.6 \pm 4.8 \mathrm{~g} / \mathrm{g}$ of swelling index (SI) at room temperature. When the temperature increased the GG-water system, the WDIS and SI did not change significantly (Fig. 2). These results suggest that GG has thermal stability under increasing temperature.


Fig. 2. Swelling index (g water/g-gum) and water dispersion (\%) of G. ulmifolia gum.

\subsubsection{Viscosity assay}

Looking for possible technological applications of the polymeric matrices, we analyzed their viscosities response at steady state under the application of a variable shear stress. The GG viscosities to 0.5 and $1.0 \%$ (pH 5.7 dispersion) in all temperatures exhibited a non-Newtonian behavior, as their apparent viscosities decreased when the strain rate $(\mathrm{g})$ increased (Fig. 3a). The data were fitted to an Ostwald-de Waele model ( $\sigma$ $\left.=k \cdot y^{n}\right)$ and determined the consistency index $(k)$ and flow behavior index $(n)$. The coefficient of determination $\left(R^{2}\right)$ for $G G$ at $0.5 \%$ and $1.0 \%$ were 0.9921 and 0.9869 , respectively. 
(a)

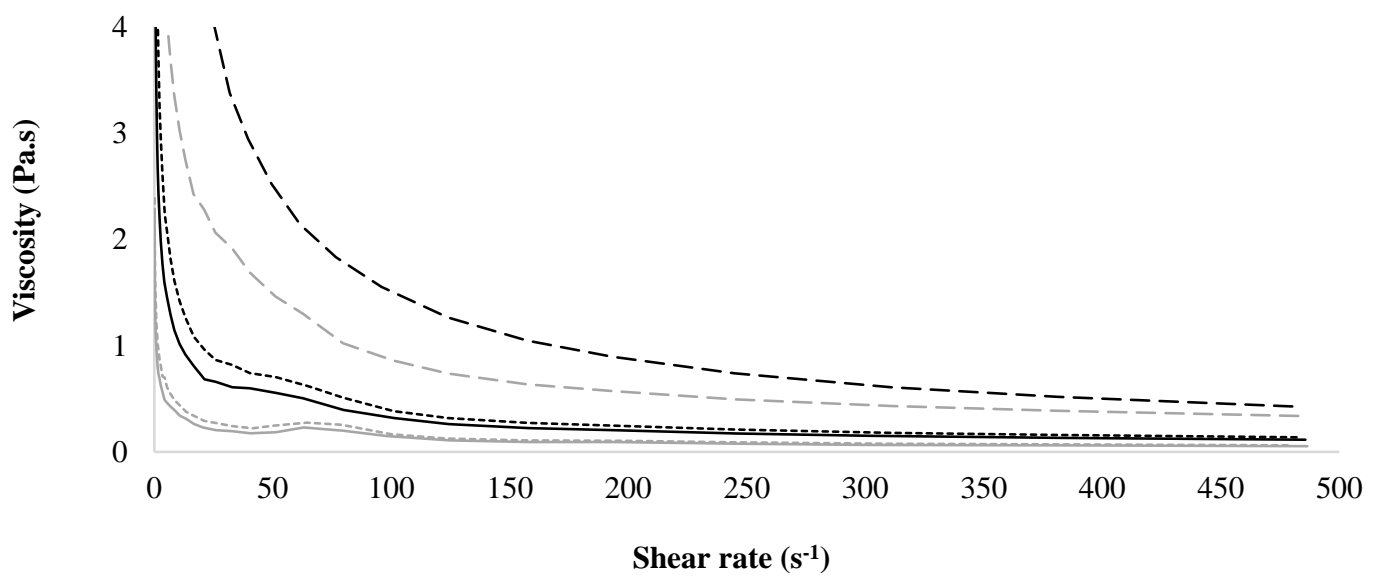

(b)

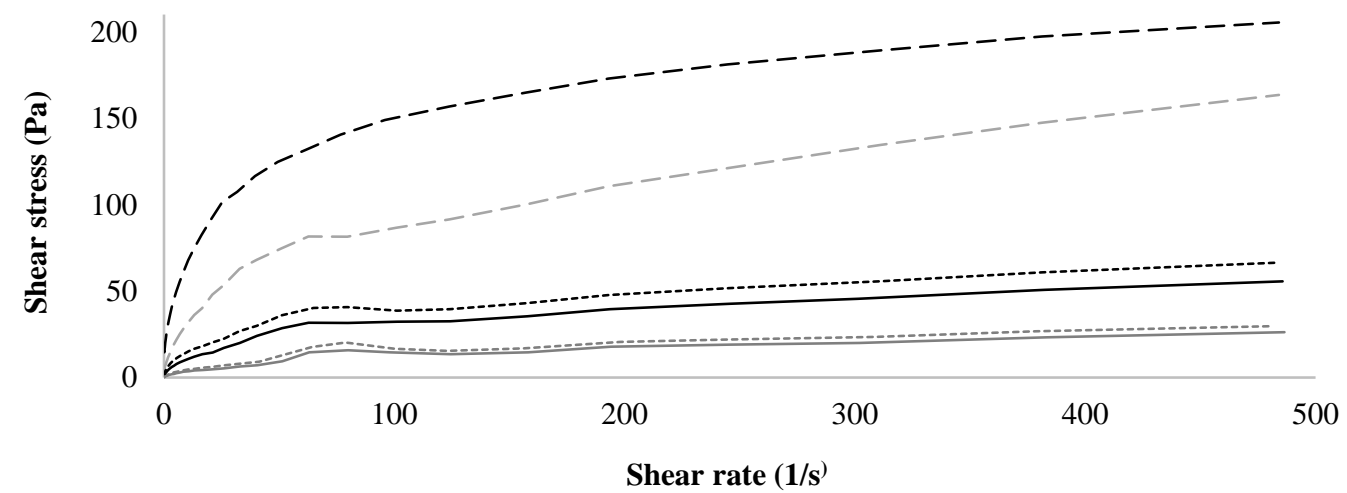

$---\cdot$ GG $1.0 \%$ at $15^{\circ} \mathrm{C}$

GG $0.5 \%$ at $15^{\circ} \mathrm{C}$

GG $1.0 \%$ at $25^{\circ} \mathrm{C}$

GG $0.5 \%$ at $25^{\circ} \mathrm{C}$

GG $1.0 \%$ at $45^{\circ} \mathrm{C}$

GG $0.5 \%$ at $45^{\circ} \mathrm{C}$

Fig. 3. Rheological behavior of G. ulmifolia gum (GG) at 15,25 and $45^{\circ} \mathrm{C}$. (a) Viscosity curve, (b) flow curve.

At both GG concentrations viscosity decrease when temperature increased. The increase of shear rate (Fig. 3b) for two used GG concentrations showed a similar behavior of stress deformation at 25 and $45^{\circ} \mathrm{C}$. The shear stress was affected by GG concentration at the afore mentioned temperatures, having a minor shear stress in GG at $0.5 \%$.

The consistency index $(k)$ and the flow behavior index (n) indicate that both GG concentrations (0.5 and $1.0 \%$ ) behave as shear thinning fluid (pseudoplastic). The decrease of $G G$ concentration also modified significantly $\left(F_{1,2}=2030, p<0.0001\right)$ the consistency index (Table 2). The increase in temperature affected significantly $\left(F_{2,2}=\right.$ $112, p<0.0001$ ) the GG consistency, with a total decrease up to $40 \%$ for $1.0 \%$ GG. On the other hand, the decrease of GG concentration improved significantly the fluidity up to $20 \%$ (Table 2). The GG fluidity increased significantly almost in all cases with the high temperatures $\left(F_{2,2}=79, p<0.0001\right)$ and $G G$ concentration $\left(F_{1,2}=1350, p<0.0001\right)$, except in $45^{\circ} \mathrm{C}$ with an opposite pattern (Table 2). 
Table 2. Consistency and flow behavior index of G. ulmifolia gum (GG) at 15, 25 and 45 ${ }^{\circ} \mathrm{C}$

\begin{tabular}{ccccccc}
\hline GG & \multicolumn{3}{c}{ Consistency index (Pa.s) } & \multicolumn{3}{c}{ Flow behavior index (n) } \\
Conc. & $\mathbf{1 5}{ }^{\circ} \mathbf{C}$ & $\mathbf{2 5}{ }^{\circ} \mathbf{C}$ & $\mathbf{4 5}{ }^{\circ} \mathbf{C}$ & $\mathbf{1 5}^{\circ} \mathbf{C}$ & $\mathbf{2 5}{ }^{\circ} \mathbf{C}$ & $\mathbf{4 5}{ }^{\circ} \mathbf{C}$ \\
\hline $\mathbf{0 . 5 \%}$ & $1.54 \pm 0.12 \mathrm{Aa}$ & $1.38 \pm 0.07 \mathrm{ABa}$ & $0.99 \pm 0.08 \mathrm{Ba}$ & $0.48 \pm 0.01 \mathrm{Aa}$ & $0.49 \pm 0.01 \mathrm{Aa}$ & $0.52 \pm 0.01 \mathrm{Ba}$ \\
$\mathbf{1 . 0 \%}$ & $6.60 \pm 0.12 \mathrm{Ab}$ & $5.11 \pm 0.28 \mathrm{Bb}$ & $3.95 \pm 0.29 \mathrm{Cb}$ & $0.37 \pm 0.01 \mathrm{Ab}$ & $0.40 \pm 0.01 \mathrm{Bb}$ & $0.42 \pm 0.01 \mathrm{Cb}$ \\
\hline
\end{tabular}

Different capital letters indicate significant differences among temperatures, and different lowercase letters indicate differences between GG concentrations (Pairwise contrast Tukey, $P \leq 0.05$ ).

\subsection{Effect of GG on the entomotoxic activity of Metarhizium anisopliae (MET)}

For the bioassay two GG concentrations $(0.2 \%$ and $0.5 \%)$ were used in the conidial suspension of MET that was sprayed to $B$. tabaci-infested leaves. These leaves had an average density of $5.4 \pm 2.0$ nymphs $\mathrm{cm}^{2}$. Nymphal mortality (Fig. 4) showed significant differences $\left(F_{5,7}=19.5, P<0.001\right)$ among MET treatments. The treatment MET-GG $0.5 \%$ showed the highest activity on $B$. tabaci nymphs, recorded mortality was $91.1 \pm 8.9 \%$. Nymphal mortality caused by MET-GG $0.2 \%$ was not significantly different (Pairwise contrast Tukey, P $\geq 0.05$ ) to that caused by MET-bare spore (49.2 \%; Fig. 4).



Fig. 4. Effects of $G G$ as carrier matrix on the entomotoxic activity of MET against Bemisia tabaci nymphs. MET: Metarhizium anisopliae; GG: G. ulmifolia gum. Different letters indicate significant differences among treatments, bars on each column represent the standard error (Pairwise contrast Tukey, $\mathrm{P} \leq 0.05$ ).

\section{DISCUSSION}

Natural gums are promising material with biotechnological applications. They are nontoxic, stable, easily available, and associated with less regulatory issues as compared to their synthetic counterpart (Avachat et al., 2011). In the present work, we evaluated the hydration properties of $G G$ and its potential as carrier agent for an entomopathogenic 
fungus. The GG yield was relatively low $(67.1 \mathrm{~g} / \mathrm{kg}$ ) in comparison to seed gum from other plant species, like D. regia $(400 \mathrm{~g} / \mathrm{kg})$ and O. basilicum $(200 \mathrm{~g} / \mathrm{kg})($ Hosseini et al., 2010; Pacheco-Aguirre et al., 2010). Nevertheless, the gum yield was similar to that of $S$. japonica seed $(92.2-33.3 \mathrm{~g} / \mathrm{kg})$ and L. leucocephala seed $(75.2 \mathrm{~g} / \mathrm{kg})$ (Cerqueira et al., 2009; El Kader et al., 2008). The analytical data of GG shows specific characteristics. For example, the total carbohydrates were lower than that reported for D. regia seed gum (95.31\%) (Pacheco-Aguirre et al., 2010), but slightly higher than that reported for $O$. basilicum seed gum (79.63\%) (Hosseini et al., 2010) and Acacia senegal (L.) wild seed gum (84.10\%) (El-Kheir et al., 2008). In addition, the ash content was higher than values reported by commercial gums (El-Kheir et al., 2008; Elkhalifa \& Hassan, 2010), which indicates that GG had a similar purity to that of non-traditional gums.

The increase of conductivity when increase GG concentration suggests the presence of ionic charges in its chemical structure (Nedjhioui et al., 2009). This condition was observed in a good WDIS (79.6\%) of GG at room temperature, as the presence of ionic charges cause electrostatic repulsive interactions between themselves facilitating the formation of hydrogen bonds with water (Choi et al., 2003). This behavior has been also observed in GG indicating a thermal stability of their polymeric structure, which favors the potential application of $G G$ as a carrier for biological control agents that must be protected from high temperatures (Basfar et al., 2003). In the case of carriers, the swelling ability has great influence on the improvement of dissolution rate of poorly water-soluble biocides (Viral et al., 2010). Likewise, the swelling ability is used also in the retardation of release of active substances from polymeric matrix (Kadajji \& Betageri, 2011).

The viscosity is also an important characteristic of polymeric matrix to gain fundamental understanding of the processability of the material (Sadiku et al., 2011). In this case, GG had a non-Newtonian behavior indicating a disentanglement process and an increase of average end-to-end distance of polymer chains due to shearing, where the viscosity and shear stress increased with the increase of GG concentration, probably due to the formation of a polymeric network (Aalaie et al., 2007). The decrease in viscosity of both GG solutions when temperature increase indicates the thermo-dependent behavior of the solutions. Understanding the rheological behavior of polymeric melts is helpful in understanding the structure property in these materials for the formation of microbial agent carriers. We might think that the GG gum is favorable for delivering the biocide or decrease the biocide entrapment (Razavi et al., 2013).

Apart of the hydration properties of GG, the potential of this gum as carrier for microbial control agent MET conidia to enhance their entomotoxic activity was also evaluated. In this sense, we used two concentrations $(0.2 \%$ and $0.5 \%)$ of GG in the conidial suspension of MET that were sprayed on $B$. tabaci nymphs under greenhouse conditions. The use of the GG matrix at $0.2 \%$ did not enhance the activity of MET. The insecticidal activity of this treatment was not significantly different to that of MET-alone (lower than $50 \%$ ). This rate of mortality was similar to those observed in other works, where $M$. anisopliae was applied against $B$. tabaci nymphs. For example, Ruiz-Sánchez et al., (2011), Flores et al., (2012) and García et al., (2013) found that rates of mortality of $B$. tabaci nymphs ranged from 40 to $50 \%$ using bare spores of $M$. anisopliae. The increase of GG from $0.2 \%$ to $0.5 \%$ increased significantly the nymphal mortality (e.g $91.1 \pm 8.9 \%$ against $50.6 \%$ ). This effect could clearly be attributed to an increase in 
polymer concentration as well as swelling properties of the gum, which could lead to better adhesion of MET to the cuticle of $B$. tabaci nymphs. We underlie the advantage of using GG as carrier agents of MET, since they are relatively cheap, non-toxic and ecofriendly due to their natural origin (Nazarzadeh Zare et al., 2019).

The purity of gum from G. ulmifolia seed was similar to non-traditional gums. The GG showed good water dispersion and offered thermal stability under high temperatures. The GG when added to the MET spore suspension improved its effectiveness against $B$. tabaci nymphs. The GG showed good capacity of interaction with water. The typical characteristic of GG includes ionic charge gum, high solubility and stable SI. The GG showed an adequate viscosity and thermal stability at low concentrations. When evaluated as carrier and protecting agent for the biological control fungus MET, there was an increase in mortality of $B$. tabaci nymphs when increasing the GG concentrations in the spore suspension, which suggests a major retention of MET in GG. More studies of chemical and structural composition of the gum should be carried out prior to use it as new source of polymer to improve the activity of entomopathogenic fungi.

\section{ACKNOWLEDGEMENTS}

Authors thank PROMEP-SEP for the postdoctoral scholarship to JPA (Document No. PROMEP/103.5/13/4719).

\section{CONFLICT OF INTEREST}

The authors have no conflict of interest to declare.

\section{REFERENCES}

Aalaie J., Rahmatpour A. \& Maghami S. 2007. Preparation and characterization of linear low density polyethylene/carbon nanotube nanocomposites. Journal of Macromolecular Science, Part B Physics. 46: 877-889. https://doi:10.1080/00222340701389100

Alonso C.A.J. \& Salazar O.L.A. 2008. The anti-diabetic properties of Guazuma ulmifolia Lam. are mediated by the stimulation of glucose uptake in normal and diabetic adipocytes without inducing adipogenesis. Journal of Ethnopharmacology. 118(2): 252256. https://doi: 10.1016/j.jep.2008.04.007.

AOAC 1997. Official methods of analysis, Association Official Analytical Chemists. 17 th ed. Washington D.C., U.S.A.

Avachat A.M., Dash R.R. \& Shrotriya S. N. 2011. Recent investigations of plant based natural gums, mucilages and resins in novel drug delivery systems. Indian Journal of Pharmaceutical Education and Research. 45(1): 86-99.

Basfar A.A., Idriss A.K.M. \& Mofti S.M. 2003. UV stability and radiation-crosslinking of linear low density polyethylene and low density polyethylene for greenhouse 
applications. Polymer Degradation and Stability. 82(2): 229-234. https://doi.org/10.1016/S0141-3910(03)00216-7

Berenguer B., Trabadela C., Sánchez F.S., Quílez A., Miño P., De la Puerta R. \& Martín C.M.J. 2007. The aerial parts of Guazuma ulmifolia Lam. protect against NSAID-induced gastric lesions. Journal of Ethnopharmacology. 114(2): 153-160. https://doi:10.1016/j.jep.2007.07.019

Capitani, M.I. Corzo-Rios, L.J. Chel-Guerrero, L.A. Betancur-Ancona, D.A. Nolasco, S.M. Tomás, M.C. 2015. Rheological properties of aqueous dispersions of chia (Salvia hispanica L.) mucilage. Journal of Food Engineering. 149: 70-77. https: // 10.1016/j.jfoodeng.2014.09.043

Carrascosa M.B. \& Lorenzo M.F. 2013. El empleo de gomas orgánicas en la elaboración de morteros de reintegración (The use of organic gums in developing of reintegration mortars). In: Innovaciones Científicas en Adhesión ICA (Martín M.J.M., Martín R.S. \& Suárez B.J. eds). TXT editorial. España.

Cerqueira M.A., Pinheiro A.C., Souza B.W.S., Lima Á.M.P., Ribeiro C., Miranda C., Teixeira J.A., Moreira R.A., Coimbra M.A., Gonçalves M.P., \& Vicente V.V. 2009. Extraction, purification and characterization of galactomannans from non-traditional sources. Carbohydrate $\quad$ Polymers. 45: 408-414. https://doi.org/10.1016/j.carbpol.2008.07.036

Chan C.W., Ruiz-Sánchez E., Lara R.J., Reyes R.A., Cristóbal A.J., Tun S.J., Pérez G.A. \& Mendoza G.D. 2013. Pathogenicity of native isolates of Isaria fumosorosea (Deuteromycotina: Hyphomycetes) on immature whitefly Bemisia tabaci Gennadius (Hemiptera: Aleyrodidae) and their genetic variability. African Journal of Microbiology Research. 7(11): 925-931. https://doi:10.5897/AJMR12.493

El Kader D.A., Molina E.A., Montero K.C., Gutierrez O., Troncone G. \& León de Pinto G. 2008. Analytical data of seed gum from Leucaena leucocephala. Revista de la Facultad de Agronomía (LUZ). 25(1): 95-108.

Elkhalifa W.A. \& Hassan E.A. 2010. Characterization of Sterculia setigera gum (gum karaya) in Sudan. University of Africa Journal of Science. 1(1): 18-26.

El-Kheir M.K.S., Yagoub A.E.A. \& Baker A.A.A. 2008. Emulsion-stabilizing effect of gum from Acacia senegal (L) Willd. The role of quality and grade of gum, oil type, temperature, stirring time and concentration. Pakistan Journal of Nutrition. 7(3): 395399. https://doi:10.3923/pjn.2008.395.399

Faria M. \& Wraight S.P. 2001. Biological control of Bemisia tabaci with fungi. Crop Protection. 20(9): 767-778. https://doi:10.1016/S0261-2194(01)00110-7

Flores M.A., Pucheta D.M., Rodriguez N.S., De La Torre N.M. \& Ramos L.M. 2012. Mycoinsecticide effects of Beauveria bassiana, Metarhizium anisopliae, and Isaria 
fumosorosea on the whitefly Bemisia tabaci (Homoptera: Aleyrodidae) in different strata of bean. African Journal of Microbiology Research. 6(45): 7246-7252. https://doi:10.5897/AJMR12.648

Gallardo L.R. 1993. Evaluation under laboratory conditions of the mucilaginous seeds of eight species of tropical plants for the biological control of larvae of the mosquito Culex corniger (Diptera: Culicidae). Tecnología en Marcha. 12(1): 73-84.

García R.E., Pérez P.R., León E.B.L. \& Pliego M.L. 2013. Pathogenicity of Metarhizium anisopliae and Beauveria bassiana on whitefly (Bemisia tabaci). Revista Mexicana de Ciencias Agrícolas. 6: 1129-1138. https://doi:10.29312/remexca.v0i6.1277

Herlinda S., Rizkie L., Suwandi S., Susilawati S., Lakitan B., Verawaty M. \& Hasbi. 2018. Effects of high temperature and ultraviolet-C irradiance on conidial viability and density of Beauveria bassiana and Metarhizium anisopliae isolated from soils of lowland ecosystems in Indonesia. Eurasian Journal of Analytical Chemistry. 13 (6): 209-216. https://www.researchgate.net/publication/332140469

Hosseini P.S.H., Matia M.L., Gohb K.K.T., Razavi S.M.A. \& Mortazavi S.A. 2010. Steady shear flow behavior of gum extracted from Ocimum basilicum L. seed: Effect of concentration and temperature. Journal of Food Engineering. 101(3): 236-243. https://doi:10.1016/j.jfoodeng.2010.06.025

Kadajji V.G. \& Betageri G.V. 2011. Water soluble polymers for pharmaceutical applications. Polymers. 3(4): 1972-2009. https://doi:10.3390/polym3041972

Koocheki A., Mortazavi S.A., Shahidi F., Razavi S.M.A., Kadkhodaee R. \& Mohamadzadeh M.J. 2010. Optimization of mucilage extraction from qodume shirazi seed (Alyssum homolocarpum) using response surface methodology. Journal of Food Process Engineering. 33(5): 861-882. https://doi.org/10.1111/j.1745-4530.2008.00312.x

Koocheki A., Taherian A.R., Razavi S.M.A. \& Bostan A. 2009. Response surface methodology for optimization of extraction yield, viscosity, hue and emulsion stability of mucilage extracted from Lepidium perfoliatum seeds. Food Hydrocolloids. 23(8): 23692379. https://doi.org/10.1016/j.foodhyd.2009.06.014

Lopes G.C., Rocha J.C.B., Almeida G.C. \& Mello J.C.P. 2009. Condensed tannins from the bark of Guazuma ulmifolia Lam. (Sterculiaceae). Journal of the Brazilian Chemical Society. 20(6): 1103-1109. https://doi.org/10.1590/S0103-50532009000600016

Manríquez L.Y.M., López O.S., Pérez H.P., Ortega J.E., López T.Z.G. \& Villarruel F.M. 2011. Agronomic and forage characteristics of Guazuma ulmifolia Lam. Tropical and Subtropical Agroecosytems. 14(2): 453-463.

Milani J. \& Maleki G. 2012. Hydrocolloids in food industry. In: Food industrial processes - methods and equipment, (Valdez. B., ed). Publisher InTech, Rijeka, Croatia. 
Mirhosseini H. \& Amid B.T. 2012. Influence of chemical extraction conditions on the physicochemical and functional properties of polysaccharide gum from durian (Durio zibethinus) seed. Molecules. 17(6): 6465-6480. https://doi: 10.3390/molecules17066465.

Nazarzadeh Zare E., Makvandi P. \& Tay F.R. 2019. Recent progress in the industrial and biomedical applications of tragacanth gum: A review. Carbohydrate Polymers. 212: 450-467. https://doi.org/10.1016/j.carbpol.2019.02.076

Nedjhioui M., Moulai M.N., Canselier J.P. \& Bensmaili A. 2009. Investigation of combined effects of xanthan gum, sodium dodecyl sulphate, and salt on some physicochemical properties of their mixtures using a response surface method. Journal of Dispersion Science and Technology. 30: 1333-1341. https://doi.org/10.1080/01932690902735538

Norhelina L., Sajap A.S., Mansour S.A. \& Idris A.B. 2013. Infectivity of five Metarhizium anisopliae (Deuteromycota: Hyphomycetales) strains on whitefly, Bemisia tabaci (Homoptera: Aleyrodidae) infesting brinjal, Solanum melongena (Solanaceae). $\begin{array}{llll}\text { Academic Journal of } & \text { 127-132. }\end{array}$ https://doi:10.5829/idosi.aje.2013.6.3.7686

Ojeda C.M., Rodríguez V.R., Galindo V.E., Lezama G.R. \& Cruz V.C. 2011. Control of Rhipicephalus microplus (Acari: Ixodidae) using the entomopathogenic fungi Metarhizium anisopliae (Hypocreales: Clavicipitaceae). Revista Mexicana de Ciencias Pecuarias. 2(2): 177-192.

Pacheco-Aguirre J., Rosado R.G., Betancur A.D. \& Chel G.L. 2010. Physicochemical properties of carboxymethylated flamboyant (Delonix regia) seed gum. CyTA Journal of Food. 8(3): 169-176. https://doi:10.1080/19476330903322960

Pacheco-Aguirre J., Ruiz-Sánchez E., Reyes-Ramírez A., Cristóbal-Alejo J., Tun-Suárez J. \& Borges-Gómez L. 2016. Polymer-based encapsulation of Bacillus subtilis and its effect on Meloidogyne incognita in tomato. Phyton-International Journal of Experimental Botany. 85(1): 1-6.

Patel J.G., Ashish D.D., Patel A.A. \& Patel N.M. 2012. Ethnomedicinal, phytochemical and preclinical profile of Guazuma ulmifolia Lam. Pharma Science Monitor: An International Journal of Pharmaceutical Sciences. 3(2): 66-78.

Rangel D.E., Braga G.U., Flint S.D., Anderson A.J. \& Roberts D.W. 2004. Variations in UV-B tolerance and germination speed of Metarhizium anisopliae conidia produced on insects and artificial substrates. Journal of Invertebrate Pathology. 87(2-3): 77-83. https://doi:10.1016/j.jip.2004.06.007

Razavi S.M.A., Abadi M.H., Ghadiri G.R. \& Salehi E.A. 2013. Rheological interaction of sage seed gum with xanthan in dilute solution. International Food Research Journal. 20(6): 3111-3116. 
Ruiz M.C. 2009. El pixoy como material de conservación de pintura mural y relieves policromos en el área maya. Estudios de Cultura Maya. 35: 63-90.

Ruiz-Sánchez E., Chan C.W., Pérez G.A., Cristóbal A.J., Uch V.B., Tun S.J.M. \& Munguía R.R. 2011. In vitro growth, sporulation and germination of five strains of Metarhizium and their virulence on Bemisia tabaci eggs and nymphs. Revista Mexicana de Micología. 33: 9-15.

Sadiku A.O., Rotimi S.E., Adegbola A. \& Biotidara O. 2011. Rheological properties of polymers: structure and morphology of molten polymer blends. Materials Science and Applications. 2: 30-41. htpps://doi:10.4236/msa.2011.21005

Villa H.A., Nava T.M.E., López O.S., Vargas L.S., Ortega J.E. \& Gallardo L.F. 2009. Use of guacimo (Guazuma ulmifolia Lam.) as a forage source for extensive livestock production in a tropical area of Mexico. Tropical and Subtropical Agroecosytems. 10(2): 253-261.

Yin W., Wang Y., Liu L. \& He J. 2019. Biofilms: The Microbial "Protective Clothing" in Extreme Environments. International Journal of Molecular Sciences. 20(14): 3423. https://doi.org/10.3390/ijms20143423 